\title{
EDUKASI PENYAKIT KULIT, PERILAKU HIDUP BERSIH, DAN CUCI TANGAN PAKAI SABUN UNTUK SANTRI PONDOK PESANTREN MODERN ASSA'ADAH SERANG BANTEN
}

\author{
Yudhi Nugraha, Maria Silvester Thadeus, Nasihin Saud Irsyad \\ Program Studi Sarjana Kedokteran, Fakultas Kedokteran, UPN Veteran Jakarta \\ e-mail : ynugraha@upnvj.ac.id
}

\begin{abstract}
Skin infection case is still highly found in Indonesia with prevalence at 4.6-12.95\%. The highest prevalence rate was found in the pesantren. The skin infection disease that often observed in students that lives in pesantren mainly Scabies. The prevalence of scabies in pesantren found more than 43\%. This shows that the spread of skin diseases in the pesantren is still high. Actually, this coundation that caused by a microorganism infection is can be prevented easily. Hand hygiene is of utmost concern to everyone and is the earliest and most effective method of preventing the transmission of health-related pathogenic microbes. Efforts to keep hands clean is one important step to prevent disease and prevent disease transmission to others. This activity is carried out through counseling using the lecture method through the help of video media and leaflets. After that, a demonstration of how to wash hands with soap was carried out through six steps, which were then followed by all activity participants who were students in the Assaaadah Islamic Boarding School, Serang Banten Regency. This activity was successfully carried out even though in a pandemic condition that caused the boarding school to be closed completely to visitors, but with these limitations, an online approach was made to carry out the activity. The results of the activity show that 50 students of the modern Assaadah Islamic boarding school have understood the importance of washing hands with soap, the theory scabies, and the principles of clean living in a communal environment.
\end{abstract}

Key words: Scabies, Skin infection disease, Hygine

\section{Pendahuluan}

Pondok pesantren adalah sekolah Islam yang khas pada sistem asramanya. Pelajar pada pesantren biasa disebut dengan santri sedangkan gurunya biasa disebut ustad. Di Indonesia, ada lebih dari 14.000an pesantren yang telah terdata, sesungguhnya masih banyak pesantren yang belum terdata di Indonesia. Namun banyaknya pesantren di Indonesia memiliki keterkaitan data lain yang menunjukan bahwa prevalensi penyakit kulit di kalangan para santri sangatlah tinggi. Penyakit kulit sebenarnya dapat dihindari dengan perilaku hidup bersih yang sangat sederhana dapat dibiasakan mulai dari lingkungan keluarga, sekolah, bahkan diterapkan di pesantren. Usaha menjaga kebersihan sebenarnya sangat bermanfaat untuk menjaga seluruh anggota keluarga atau komunitas bahkan diri sendiri dari penyakit infeksi yang disebabkan oleh mikroorganisme (bakteri, virus, parasit) yang mayoritas penularannya dari sentuhan tangan. Direktur Kesehatan Keluarga Kementerian Kesehatan (Kemenkes) RI, menyebutkan bahwa tiap tahun lebih dari 1,7 juta anak meninggal karena diare. Data lain menunjukan bahwa berdasarkan Survei Demografi dan Kesehatan Indonesia (SDKI) 2015, 520 ribu Balita meninggal dalam setahun. Padahal usaha sederhana seperti mencuci tangan pakai sabun sebagai salah satu solusi penting penularan diare terbukti sangat berhasil menurunkan angka penularan sehingga kematian anak karena diare tersebut dapat dicegah. Cuci tangan menggunakan air tanpa menggunakan sabun, diyakini dapat membunuh kuman hanya 10 persen namun hal berbeda jika kita menggunakan sabun yang akan 
meningkatkan efektifitasnya hingga 80 persen dalam membunuh bakteri (Depkes, 2017). Pada dasarnya kebersihan tangan pada seseorang merupakan hal yang penting dari kewaspadaan tiap orang dan menjadi langkah yang penting dan terdepan dalam mencegah penularan mikroba yang menyebabkan penyakit yang berhubungan dengan kesehatan (WHO 2008). Hal ini karena tangan melalui sentuhannya, merupakan jalur penularan yang paling cepat. Sehingga disimpulkan bahwa hal kecil seperti menjaga tangan agar selalu bersih adalah salah satu langkah efisien yang dinilai penting untuk mencegah penyakit dan mencegah penularan penyakit ke orang lain (CDC 2015). Centers for Disease Control and Prevention (CDC 2016) menyatakan bahwa mencuci tangan dengan sabun adalah cara terbaik untuk mengurangi jumlah mikroba di tangan. Pada 5 Mei 2017 juga WHO telah membuat program "Aksi Cuci TanganMelawan Resistensi Antibiotik" yang tujuannya untuk setiap individu untuk giat melakukan aksi cuci tangan sebagai usaha preventif penularan penyakit.

Aksi mencuci tangan menjadi langkah utama dari program pencegahan dan pengawasan infeksi yang efektif untuk melawan resisten terhadap antibiotik ini menjadi kegiatan setiap tahun untuk membiasakan masyarakat mengingat akan pentingnya cuci tangan ini (WHO, 2017). Meskipun perilaku mencuci tangan mungkin sudah diterapkan di tiap lingkungan yang mengerti dan paham betul pentingnya kesehatan, namun sayangnya masih perlu terus dilakukan kegiatan yang menyerukan untuk mencuci tangan dengan benar sebelum dan setelah melakukan aktivitas dan langkah awal ini dimulai dari rumah. Jika langkah awal ini telah terbiasa dilakukan dalam lingkungan rumah, hal ini tentu akan membawa keluarga dan juga lingkungan ke arah perilaku hidup bersih dan sehat (PHBS). Tangan adalah alat trasmisi mikroorganisme yang utama yang menyebabkan infeksi terutama pada saluran pernafasan dan pencernaan. Mikroorganisme yang menyebabkan infeksi lewat tangan adalah dari golongan bakteri, virus, parasit dan jamur mikroskopik. Bakteri yang dapat menyebabkan infeksi antara lain dari golongan Enterobacteriaceae, misalnya Escherichia coli, Salmonella typhi, Shigella dysenteriae, Vibrio cholera, Lactobacillus. Kelompok Parasit dari jenis Ascaris lumbricoides, Trichuris, dan Entamoeba coli Sedangkan dari kelompok virus antara lain dari Family Rhinovirus, Hepatitis. (Cowan M.K et.al. 2013; Cornelissen et.al, 2015). Terkadang air yang digunakan untuk mencuci tangan adalah air yang tidak bersih banyak mengandung kuman dan bakteri penyebab penyakit. Bila digunakan untuk keperluan sehari-hari maka kuman akan berpindah ke tangan. Pada saat makan, kuman dengan cepat masuk ke dalam tubuh, yang bisa menimbulkan penyakit. Pada permukaan kulit dapat ditemukan mikroorganisme menetap (transient flora) dan mikroorganisme sementara (resident flora) (Cornelissen et.al, 2015).

Cuci tangan pakai sabun juga telah masuk dalam kategori gerakan kesehatan di lingkungan masyarakat yang baik dan efektif. Cuci tangan ini menjadi kegiatan pencegahan dalam penularan penyakit kulit yang masih tinggi di Indonesia khususnya di lingkungan pesantren. Data pada tahun 2003 misalnya, prevalensi penyakit kulit di pesantren hampir menyentuh angka 48\%. Angka tersebut masih tergolong sangat tinggi padahal penerapan PHBS di pesantren merupakan tanggung jawab setiap seluruh anggota pesantren termasuk para santri. Kewajiban edukasi tentang PHBS juga menjadi tanggung jawab pemerintah/ kota beserta jajaran sektor terkait untuk memfasilitasi kegiatan PHBS di lingkungan pesantren agar dapat dijalankan secara efektif. Secara prinsipn, Cuci Tangan Pakai Sabun (CTPS) adalah kegiatan cuci tangan dengan proses mekanik menggunakan air bersih yang mengalir dan sabun (Permenkes RI. Permenkes RI Nomor 3 tahun 2014 tentang Sanitasi Total Berbasis Masyarakat. 2014). Program cuci tangan pakai sabun merupakan langkah awal yang mudah dan sangat sederhana dari Perilaku Hidup Bersih dan Sehat (PHBS) di rumah tangga yang merupakan upaya untuk memberdayakan anggota rumah tangga agar sadar, mau dan mampu melakukan PHBS untuk memelihara dan 
meningkatkan kesehatannya secara pribadi, mencegah resiko terjadinya penyakit, dan melindungi diri dari ancaman penyakit khususnya penyakit infeksi. Program penting pemerintah dalam mewujudkan Indonesia bersih, sehat dan berkualitas, perlu dimulai dengan hal-hal yang sederhana dan konkrit di lingkungan, seperti edukasi kepada masyarakt maupun para santri akan pentingnya menjaga kebersihan dan kesehatan, baik kebersihan diri pribadi serta peduli akan kondisi lingkungan sekitar.

Salah satu pesantren yang berlokasi di Kabupaten Serang, yang merupakan lokasi Kerjasama antara Universitas Pembangunan Nasional Veteran Jakarta dengan Pemda Serang adalah Pondok Pesantren Assa'adah. Pondok Pesantren Assa'adah merupakan salah satu pondok pesantren terbesar dan sudah berdiri sejak tahun 1985. Pesantren ini merupakan pesantren modern yang memiliki banyak prestasi dan mengakomodir kegiatan ekstrakulikuler robotik, jurnalistik, sains, bahkan marching band. Pondok Pesantren yang memiliki penerapan Bahasa Arab dan Bahasa Inggris di kegiatan sehari-harinya ini terletak di Kecamatan Cikeusal Kabupaten Serang Banten dengan jarak sekitar lebih kurang 92 KM dari UPN Veteran Jakarta

Kegiatan dari penyuluhan tentang perilaku hidup bersih dan sehat dimulai dari cuci tangan pakai sabun ini diharapkan dapat memberikan informasi tambahan kepada masyarakat di wilayah sehingga dapat menggalakkan perilaku hidup sehat dan mencegah penyakit infeksi dimulai dari hal paling sederhana yakni dari mencuci tangan yang baik dan benar dimulai dari lingkungan pesantren. Selain itu, pengetahuan tentang scabies juga menjadi salah satu materi yang disampaikan pada kegiatan pengabdian masyarakat di Pondok Pesantren Assa'adah ini.

\section{Metode}

Kegiatan pengabdian masyarakat ini dilakukan dengan bekerjasama dengan pihak mitra dalam hal ini adalah Pembina Pondok Pesantren Assa'Adah Kecamatan Cikeusal Serang Banten. Awalnya dilakukan koordinasi dan perizinan pada pihak mitra. Koordinasi di lokasi mitra dilakukan untuk mendapatkan berbagai informasi yang valid tentang kondisi lingkungan pesantren. Hasil konsultasi tersebut memberikan kepastian bahwa pentingnya mencuci tangan menggunakan sabun serta kebiasaan hidup bersih merupakan salah satu yang penting untuk disampaikan langsung. Sasaran yang dituju adalah santrisantri yang ada di lingkungan pondok pesantren dengan jumlah sekitar 50 orang.

Penyuluhan yang dilakukan adalah dengan metode ceramah secara langsung maupun daring. Alat peraga bantu penyampaian menggunakan media video dan leaflet. Pengabdian masyarakat ini dilaksanakan di lingkungan Pondok Pesantren Assaadah Kecamatan Cikeusal, Kabupaten Serang, Propinsi Banten. Kegiatan ini telah dilaksanakan pada bulan Oktober 2020 dengan responden lebih dari 50 santri Pondok Pesantren Assaadah

Penyuluhan dilakukan di Aula Santri atau tempat yang telah ditentukan pengurus pesantren setempat. Memperkenalkan tentang PHBS dan video tentang cuci tangan pakai sabun (CTPS) yang digalakkan oleh WHO. Pada akhir kegiatan seluruh peserta diminta mempraktekkan cara cuci tangan pakai sabun yang baik dan benar.

\section{Hasil Dan Pembahasan}

Kegiatan pengabdian kepada masyarakat berupa penyuluhan tentang pentingnya penggunaan sabun untuk cuci tangan serta prilaku hidup bersih terutama pada masa pandemi COVID-19 di lingkungan pondok pesantren assadah. Pesantren ini didirikan pada tahun 1985, menggunakan nama dari tempat mufakat tokoh pendiri yakni Masjid Jami' As-Sa'adah. Secara kegiatan pengajaran Pondok Pesantren Modern Assa'adah mengacu kepada standar isi dan arahan dari Departemen Agama dan Depertemen Pendidikan Nasional dan berafiliasi kepada Pondok Pesantren Modern Darussalam Gontor dalam hal pembinaan 
kepribadian santri. Walaupun format proses pembelajaran didesign modern, namum Pondok Pesantren Modern Assa'adah dalam prakteknya tetap melestarikan budaya pesantren tradisional dengan tetap mengajarkan kajian kajian kitab-kitab klasik.

Sasaran dari kegiatan ini adalah santri yang sering sekali memiliki permasalahan kesehatan yang berkaitan dengan kebersihan lingkungan, untuk itu diharapkan dari kegiatan penyuluhan ini santri-santri mendapatkan tambahan pengetahuan tentang pentingnya cuci tangan pakai sabun dan kebiasaan hidup bersih.

Pelaksanaan kegiatan secara on the spot di Pondok Pesantren Assaadah terhambat dengan adanya Pandemi COVID-19. Setelah berkomunikasi virtual pada bulan Maret 2020 dengan pengurus pesantren disepakati bahwa kegiatan akan dilakukan setelah pandemic COVID-19. Namun karena sampai pada bulan Oktober 2020 pandemi belum berakhir dan tidak diketahui kapan akan berakhir, sehingga setelah berkomunikasi kembali dengan pihak pengelola pesantren melahirkan kesepakatan bahwa kegiatan akan dilakukan secara daring melalui google meet atau platform Zoom pada akhir bulan Oktober 2020. Sebanyak 50 santri menjadi peserta penyuluhan ini. Secara gender, paling banyak didominasi dari usia 14-16 tahun.

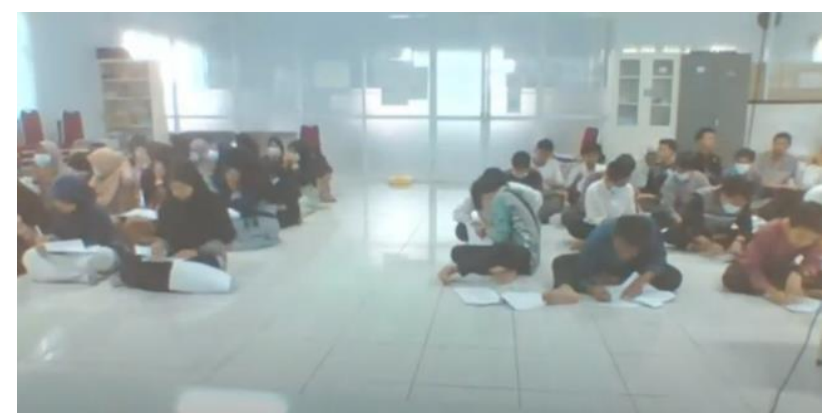

Gambar 1. Foto Kegiatan Santri Saat Mengerjakan Pretest sebelum kegiatan berlangsung (Sumber; Dokumen Pribadi)

Pendidikan rata-rata santri yang mengikuti kegiatan ini adalah duduk pada tingkat SMP dan sedang melanjutkan SMA dan sebagian besar mendapatkan informasi tentang pentingnya cuci tangan pakai sabun dari para senior santri dan ustad, karena memang sebenarnya informasi tentang kebersihan ini telah menjadi aturan baku dalam kehidupan di Pesantren ini.

Data data yang dihimpun juga menunjukan bahwa edukasi tentang kesehatan dan kebersihan di lingkungan Pondok Pesantren Assa'adah sudah sangat baik, bahkan pesantren ini telah terafiliasi memiliki klinik kesehatan dan juga divisi khusus yang menangani santri ketika sakit. Hal ini jarang dijumpai terutama di pesantren non modern.

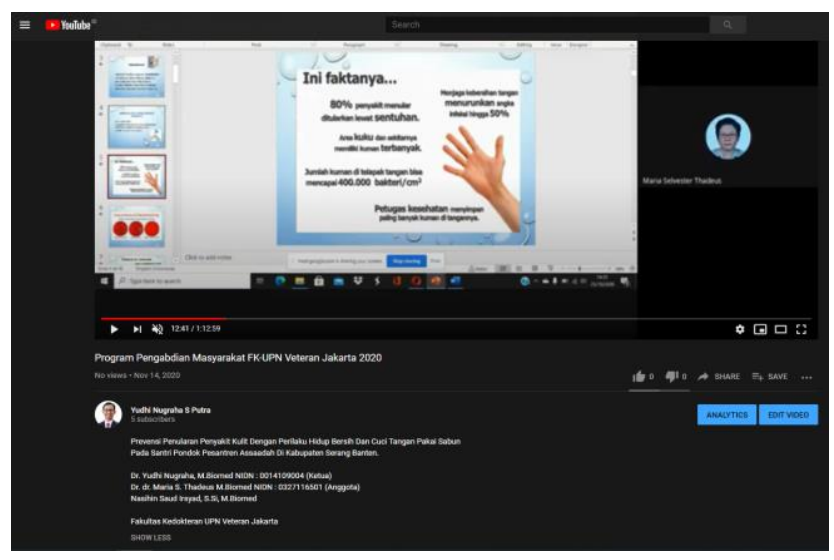


Gambar 2. Foto Tangkapan Layar Dokumentasi Kegiatan Yang telah diunggah pada Platform Youtube (Rekaman ini dapat diakses pada https://www.youtube.com/watch?v=f-pXna-6fsw)

Hasil dari quisioner yang dibagikan terlihat bahwa para santri menyadari pentingnya mencuci tangan, namun kesadaran urgensi mencuci tangan menggunakan sabun pada saat cuci tangan masih rendah untuk dipraktekan di kegiatan sehari-hari para santri. Para santri juga sudah memahami bahwa scabies dapat ditularkan, meskipun belum mengetahui bahwa scabies disebabkan oleh tungau parasite Sarcoptes scabiei. Santri juga sudah menerapkan hidup bersih seperti menyapu dan membersihkan kamar setiap hari, sayangnya para santri belum banyak yang memahami bahwa menjemur kasur secara reguler adalah hal penting dalam prinsip hidup bersih. Para kegiatan ini juga santri faham dan hafal tentang enam langkah mencuci tangan menggunakan sabun dengan baik dan benar. Edukasi tentang langkah-langkah cuci tangan dengan sabun ini juga menggunakan kegiatan menyanyi dan praktik langsung untuk memudahkan para santri mengingat langkah-langkah mencuci tangan menggunakan sabun secara urut dan benar.

Keberhasilan pelaksanaan kegiatan pengabdian kepada masyarakat ini dapat dilihat dari ketercapaian target jumlah peserta, ketercapaian tujuan dan ketercapaian target materi. Peserta yang hadir adalah 53 orang (lebih dari target, Ketercapaian tujuan dari kegiatan penyuluhan ini juga dapat dikatakan baik dari hasil pretest dan posttest. Hasil uji paired T-test diperoleh nilai signifikansi $<0,05$. Hal ini menunjukkan adanya perbedaan yang bermakna antara nilai Pre test dan Post test untuk variable Pengetahuan, sehingga bisa disimpulkan bahwa terdapat pengaruh dari pemberian penyuluhan terhadap pengetahuan peserta penyuluhan terhadap pentingnya cuci tangan pakai sabun dan kebiasaaan hidup bersih

Demikian pula untuk variabel sikap dan tindakan, berdasarkan uji paired T-test diperoleh nilai signifikansi $<0,05$. Hal ini menunjukkan adanya perbedaan yang bermakna antara nilai Pre test dan Post test. Sehingga dapat disimpulkan bahwa terdapat pengaruh dari pemberian penyuluhan terhadap sikap dan tindakan peserta penyuluhan terhadap pentingnya cuci tangan pakai sabun. Ketercapaian target materi dapat dikatakan cukup baik (100\%), hal ini dapat dilihat dari semua materi penyuluhan yang disampaikan oleh tim pengabdi dapat diterima dengan baik oleh para santri.

\section{Kesimpulan}

1. Program pengabdian kepada masyarakat di lingkungan Pondok Pesantren Modern Assa'adah ini telah terlaksana dengan baik bahkan pada saat pandemic dengan menggunakan platform googlemeet sehingga mendapatkan antusiasme yang tinggi dari para santri

2. Santri Pondok Pesantren Modern Assa'adah telah memiliki pengetahuan yang baik tentang scabies, cuci tangan menggunakan sabun, dan kebiasaan hidup bersih di lingkungan komunal seperti pesantren sehingga dapat diterapkan langsung pada kehidupan sehari-hari.

\section{Saran}

1. Sebaiknya kegiatan pengabdian ini berkelanjutan sehingga penerapan dan pelayanan kesehatan di Pondok Pesantren Assa'adah dapat secara rutin dapat ditingkatkan

2. Pondok pesantren Assa'adah telah menerapkan prilaku hidup bersih yang baik sehingga dibutuhkan pesantren yang memiliki kualitas penerapan kebersihan yang masih membutuhkan edukasi dan bimbingan dari FK UPNVJ

3. Para dokter dari FK UPNVJ dapat datang secara langsung untuk melakukan pemeriksaan status kebersihan para santri di lingkungan pesantren (setelah pandemi COVID-19 usai) 
4. Adanya Kerjasama antara Fakultas Kedokteran UPN Veteran Jakarta dan Pengelola Pesantren akan berdampak baik secara langsung bagi Kesehatan santri.

\section{Ucapan Terima Kasih}

Penulis mengucapkan terima kasih kepada para pengurus Pondok Pesantren Modern Assa'adah yang sangat membantu kegiatan pengabdian masyarakat ini. Penelitian ini didanai langsung oleh LPPM Universitas Pembangunan Nasional Veteran Jakarta (UPNVJ) melalui SK Rektor Nomor 350/UN61.0/HK.02/2020 Tahun Anggaran 2020

\section{Daftar Pustaka}

CDC. 2015, 'When \& How to Wash Your Hands',

CDC 2016, 'Show Me the Science - When to Use Hand sanitizer'

Cornelissen , Cynthia Nau; Bruce D. Fisher \& Richard A. Harvey; 2015. Lippincot's Illustrated ReviewsIlustrasi Berwarna Mikrobiologi. Edisi Ketiga, Jilid I. Binarupa Aksara. Jakarta.

Cowan M.K et.al. 2013. Microbiology Fundamentals A Clinical Approach. McGraw-Hill companies Inc. New York.

Depkes RI Pusat Promosi Kesehatan (Promkes), 2009. Rumah Tangga Sehat Dengan Perilaku Hidup Bersih Dan Sehat.

Depkes, 2017. Cuci Tangan Pakai Sabun Cegah Kematian Anak.

WHO 2008, Penerapan Kewaspadaan Standar di fasilitas pelayanan kesehatan', diakses 28 November 2015.

WHO 2009, 'Hand Hygiene: Why, How \& When?',

WHO, 2017. Clean care is safer care. 